\title{
Jatkuvatoiminen ravinnekuormituksen seurantaverkosto Kirmanjärven valuma-alueella
}

\author{
Mari Räty ${ }^{1}$, Kirsi Järvenranta ${ }^{1}$, Perttu Virkajärvi ${ }^{1}$, Erkki Saarijärvi ${ }^{2}$ ja Hanna Kröger $^{3}$ \\ 1) Maa- ja elintarviketalouden tutkimuskeskus MTT, Kotieläintuotannon tutkimus, Halolantie 31 A, \\ 71750 Maaninka, etunimi.sukunimi(at)mtt.fi \\ 2) Vesi-Eko Oy Water-Eco Ltd, Yrittäjäntie 12, 70150 Kuopio, erkki.saarijarvi(at)vesieko.fi \\ 3) Savonia-ammattikorkeakoulu, Ympäristötekniikka, PL 6 (Microkatu 1), 70201 Kuopio, \\ hanna.kroger.hkg(at)gmail.com
}

\section{TIIVISTELMÄ}

Valuma-alueen maankäyttömuodot ja viljelykäytännöt vaikuttavat fosforikuormituksen määrään ja laatuun. Nurmelle pintaan levitetty lannoitefosfori ja lietelanta kerryttävät huuhtoumalle altista fosforia maan pintakerrokseen. Nurmialueilta pintavesiin huuhtoutuvasta fosforista valtaosa on liukoista, leville suoraan käyttökelpoisena pidettyä fosforia. Suomen peltoalasta yli kolmannes on nurmia, joten niiden ravinnekuormituksen tunteminen on tärkeää vesiensuojelun kannalta. Tämän tutkimuksen tavoitteena on selvittää nurmenviljelyalueelta tulevan kuormituksen määrä ja dynamiikka pienen valuma-aluetason mittakaavassa.

MTT Maaninka perusti vuonna 2010 valuma-aluetason automaattisen ja jatkuvatoimisen ravinnekuormituksen seurantaverkoston Pohjois-Savoon Kirmanjärvelle. Tutkimusvaluma-alueen $\left(3,0 \mathrm{~km}^{2}\right)$ peltoprosentti on 32, metsän osuuden ollessa $50 \%$ ja soiden $18 \%$. Nurmien osuus peltoalasta on merkittävä. Vallitseva maalaji on hiekkamoreeni, mutta pellot ovat hienojakoisia lajittuneita kivennäismaita. Seurantaverkosto koostuu viidestä eri mittauspisteestä, joista jokainen sisältää ohjelmoitavan näytteenotto- ja virtaamamittauslaitteiston. Seuranta-alueet, joiden ojissa mittauspisteet sijaitsevat, vaihtelevat maankäytöltään peltovaltaisesta (pelto-\% 100) metsävaltaiseen (metsä-\% lähes 100). Valumaalueella sijaitsee kosteikko (1,7 ha; kosteikko/valuma-alue -suhde 1,7\%), jota on kunnostettu paikallisen metsästysseuran toimesta. Kaksi mittauspisteistä sijaitsee kosteikkoon laskevissa ojissa ja yksi on välittömästi kosteikon alapuolella, joten kosteikkoon tulevan ja sieltä lähtevän veden laatua voidaan seurata. Virtaama lasketaan paineantureiden ja V-mittapadosta saatavien vedenkorkeustietojen avulla tai mitataan akustisella virtaamamittarilla. Vesinäytteistä määritetään kokonaisfosfori, liukoinen fosfori, kiintoaines, kokonaistyppi, nitraattityppi, ammoniumtyppi, liukoinen orgaaninen hiili, liukoinen kalsium, pH ja sähkönjohtokyky.

Vuonna 2011 sademäärä oli noin $690 \mathrm{~mm}$ ja sateisen vuoden 2012 vuosisadanta oli noin 800 mm. Koko tutkimusvaluma-alueella kokonaisfosforin huuhtouma oli keskimäärin $0,6 \mathrm{~kg} \mathrm{ha}^{-1} \mathrm{a}^{-1} \mathrm{ja}$ peltoviljelyalueella $1,0 \mathrm{~kg} \mathrm{ha}^{-1} \mathrm{a}^{-1}$. Liukoisena oleva fosfori muodosti lähes puolet vesinäytteiden kokonaisfosforista, mutta sen osuus vaihteli paljon näytteenottopisteen ja -ajan suhteen. Metsäalueelta tulevan ojaveden ajoittain korkeat fosforipitoisuudet olivat seurausta pistemäisestä kuormituslähteestä, joka nosti fosforihuuhtoumaa luonnontilaisiin metsäalueisiin verrattuna. Peltoviljelyalueelta tulevan typen kuormitus (26 kg ha $\left.{ }^{-1} \mathrm{a}^{-1}\right)$ oli moninkertainen metsäalueeseen $\left(2,3 \mathrm{~kg} \mathrm{ha}^{-1} \mathrm{a}^{-1}\right)$ verrattuna.

Suurin osa ravinnekuormituksesta syntyy lumen sulamisen aiheuttaman ylivaluman aikana. Virtaama ja ravinnekuormitus vaihtelevat vuositasolla voimakkaasti riippuen etenkin hydrologisista tekijöistä, minkä takia nurmialueilta tulevan kuormituksen luotettava arviointi edellyttää monivuotista seurantatutkimusta.

\section{ASIASANAT}

Fosfori, typpi, hajakuormitus, jatkuvatoiminen veden laadun seuranta, valuma-alue, nurmenviljely, sisävesistöt 


\section{Johdanto}

Valuma-alueen maankäyttömuodot ja siellä toteutettavat toimenpiteet kuten erilaiset viljelykäytännöt vaikuttavat ravinnekuormituksen määrään ja laatuun (esim. Puustinen ym. 2007). Eroosioalttiilta hie-nojakoiselta savimaalta fosfori kulkeutuu pintavalunnassa suurelta osin kiintoaineksen mukana, kun taas karkeilla kivennäismailla olevilta nurmenviljelyalueilta huuhtoutuvasta kokonaisfosforista valta-osa voi olla liukoista, leville suoraan käyttökelpoisena pidettyä fosforia. Pitkään jatkuneessa suorakyl-vössä, nurmenviljelyssä tai laidunnurmella lannoitteista, kasvinjäänteistä sekä sonnasta peräisin olevaa helppoliukoista fosforia voi kertyä valumaveden kanssa kosketuksissa olevaan maan pintakerrokseen (Saarijärvi ym. 2006, Muukkonen ym. 2007, Saarela ja Vuorinen 2010), mikä lisää pintamaan kuormi-tuspotentiaalia. Pintamaan korkean fosforitason on osoitettu lisäävän valumaveden fosforipitoisuutta (Sharpley 1995, Turtola ja Yli-Halla 1999). Nurmilta on koeolosuhteissa mitattu huuhtoutuvan pinta-valunnan mukana huomattavia määriä fosforia, n. 1-2 $\mathrm{kg} \mathrm{ha}^{-1} \mathrm{a}^{-1}$, josta liukoisena olevan fosforin osuus voi olla jopa 80-95 \% (Turtola ja Kemppainen 1998, Saarijärvi ym. 2006). Lisäksi nurmenvilje-lyalueilta tulevan fosforikuormituksen on havaittu olevan selvästi kevätpainotteista: MTT:n Maanin-gan lysimetrikentällä jopa $90 \%$ vuotuisesta pintavalunnan fosforikuormituksesta syntyi lumen sulamisjakson aikana (julkaisematon aineisto).

Suurin osa nurmenviljelystä on keskittynyt Pohjois-Savoon sekä Etelä-, Keski- ja Pohjois-Pohjanmaalle. Pohjois-Savon vesistöjen ekologinen tila on valtaosiltaan vähintään hyvä, mutta tyydyt-tävän ja välttävän luokituksen vesien osuus on merkittävä etenkin Iisalmen reitillä. Alueelle on asetet-tu maatalouden osalta huomattavia kuormituksen vähentämistavoitteita (PohjoisSavon ELY-keskus 2010). Koska Suomen peltoalasta noin kolmannes on nurmia (MMM TIKE 2013), on vesiensuojelun kannalta tärkeää tuntea nurmenviljelyalueelta tulevan ravinnekuormituksen suuruus sekä vähentämis-keinojen käyttökelpoisuus nimenomaan nurmenviljelyssä.

Tämän tutkimuksen tavoitteena on mitata veden virtaamaa ja laatua kolmen hydrologisen vuo-den ajan (2011-2014) ja selvittää nurmenviljelyalueelta tulevan vesistökuormituksen määrä ja dyna-miikka pienen valuma-aluetason mittakaavassa.

\section{Aineisto ja menetelmät}

Vuonna 2010 hankittiin MTT:n ja MMM:n rahoittamassa Fokus-hankkeessa nurmi- ja lumi-Suomen alueen valuma-aluetason automaattinen ja jatkuvatoiminen ravinnekuormituksen seurantalait-teisto ja se sijoitettiin maanomistajien luvalla Pohjois-Savoon, Kirmanjärvelle Ruostepuron osavalu-ma-alueelle. Kirmanjärvi (pinta-ala noin $5 \mathrm{~km}^{2}$ ) toimii Ylä-Savon Vesi Oy:n varavesilähteenä ja teko-pohjaveden raakavesilähteenä, ja sen ekologista tilaa heikentävät korkeat klorofyllipitoisuudet (Poh-jois-Savon ELY-keskus 2010). Kirmanjärven koko valuma-alue on n. 27 $\mathrm{km}^{2}$, josta peltoa on $31 \%$ (Kauppinen 2006).

Ruostepuron $3,0 \mathrm{~km}^{2}:$ n kokoisella tutkimusvaluma-alueella pelto- $\%$ on 32 , metsän osuuden ol-lessa $50 \%$ ja soiden $18 \%$ (Kauppinen 2006). Seuranta-alueet, joiden ojissa viisi mittauspistettä sijait-sevat, vaihtelevat maankäytöltään peltovaltaisesta (pelto-\% 100) metsävaltaiseen (metsä-\% lähes 100; sisältää haja-asutusta) (Kuva 1). Vallitseva maalaji on hiekkamoreeni, mutta peltojen muokkausker-rokset ovat hienojakoisia hiesuvaltaisia kivennäismaita. Viljelykasveina alueella viljellään pääasialli-sesti rehunurmea ja -viljaa, nurmien osuuden ollessa merkittävä. Peltojen muokkauskerroksen helppo-liukoisen fosforin pitoisuus oli keskimäärin 12,6 $\mathrm{mg} \mathrm{l}^{-1}$ maata, mikä vastaa Viljavuuspalvelu Oy:n tilastojen mukaan tarkastelujaksolla 2006-2010 koko maan keskimääräistä fosforipitoisuutta $12,3 \mathrm{mg} \mathrm{P} \mathrm{l}^{-1}$ maata; Pohjois-Savo alueella se oli $10,6 \mathrm{mg} \mathrm{P} \mathrm{l}^{-1}$ maata. Tulosten tulkinnan yhteydessä tullaan hyödyntämään tiloilta saatavia päivitettyjä tietoja viljelykäytännöistä ja lohkojen viljavuusanalyysitu-loksista.

Seuranta-alueella sijaitseva Sumppilampi (mittauspiste 2) on ollut vesijättöalue, joka on vuonna 1995 rakennettu lintukosteikoksi. Pinta-alaltaan 1,7 ha olevan kosteikon valuma-alue on kooltaan n. 99 ha ja sen pelto- $\%$ on 56; kosteikon pinta-alan suhde sen yläpuolisen valuma-alueen pinta-alaan on 1,7\%. Paikallinen metsästysseura on kunnostanut umpeenkasvanutta kosteikkoa syksyn 2012 ja ke-vään 2013 välisenä aikana. Kosteikkojen kunnostamistöiden vaikutuksista veden laatuun on Suomessa edelleenkin varsin vähän tietoa. Seurantaverkoston mittauspisteistä kaksi sijaitsee kosteikkoon laske-vissa ojissa ja yksi on välittömästi kosteikon alapuolella. Siten kosteikkoon tulevan ja sieltä lähtevän veden laatua ja määrää voidaan seurata. Tulokset ovat valmistumassa ja siten niitä ei vielä esitetä tässä tekstissä. 


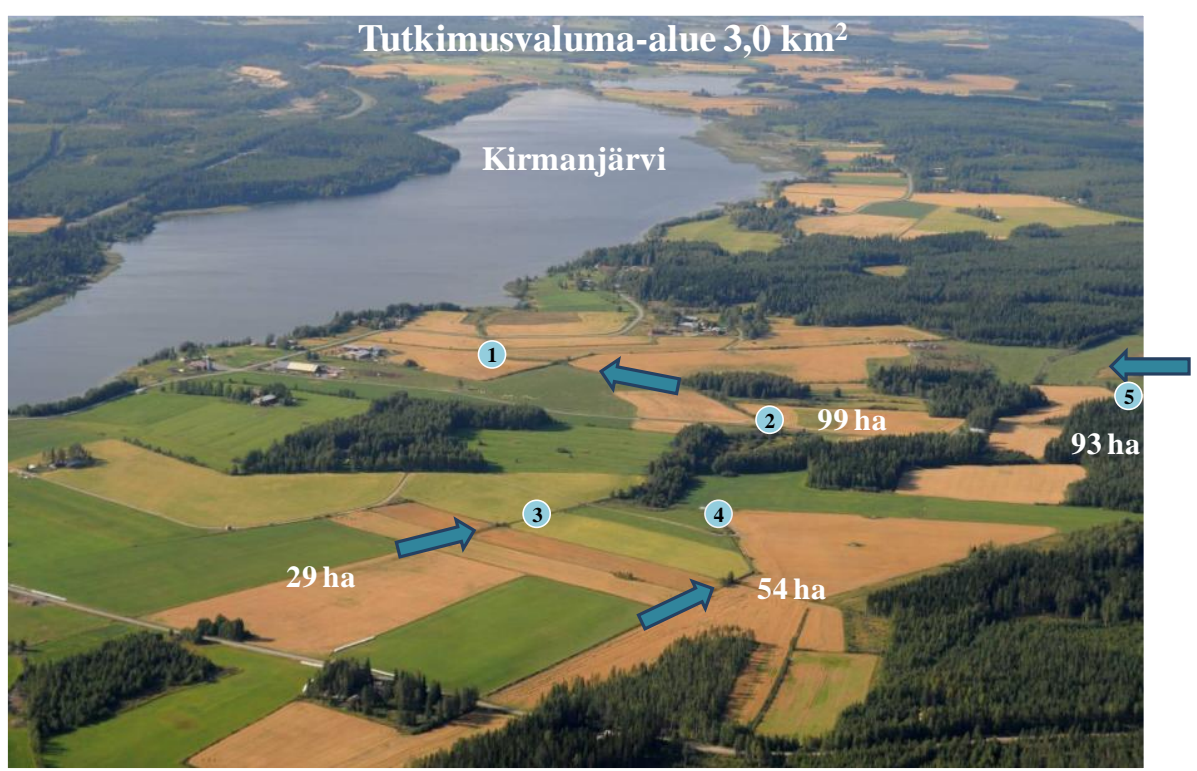

Kuva 1. Ravinnekuormituksen seurantaverkoston viisi mittauspistettä Ruostepuron osavaluma-alueen $\left(3,0 \mathrm{~km}^{2}\right)$ ojissa Pohjois-Savossa Iisalmessa. 1 = Kirmanjärveen laskevassa Ruostepurossa oleva mittauspiste, $2=$ Sumppilammen kosteikon alapuolella oleva mittauspiste, $3=$ peltovaltainen seuranta-alue (pelto-\% 100), $4=$ pelto- ja metsävaltainen seuranta-alue (pelto-\% n. 50, metsä-\% n. 50) ja $5=$ metsävaltainen seuranta-alue (metsä-\% lähes 100; sisältää myös haja-asutusta). Kuva: MTT/Perttu Virkajärvi.

Koska nurmilta tuleva fosfori on pääosin liukoisessa muodossa eikä sen pitoisuutta voida epäsuorasti arvioida veden esim. sameuden perusteella, hankittiin tarkoitukseen soveltuvat näytteenottolaitteet. Ravinnekuormituksen seurantaverkosto koostuu sääasemasta ja viidestä eri mittauspisteestä, joista jokainen sisältää lämpöeristettyyn näytteenottokoppiin sijoitetun ohjelmoitavan näytteenottimen ( $\mathrm{Li}$ quiport 2000 RPT20) sekä virtaamamittauslaitteiston manuaalisesti purettavine dataloggereineen (Kuva 2). Tutkimusvaluma-alueelle on vedetty pintakaapeli, ja siten sähkö tuotetaan mittauslaitteisiin verkkovirralla. Lisäksi näytteenottokopit ovat tarvittaessa lämmitettäviä ja lämpökaapeleiden avulla ojauomiin menevät näytteenottoputket voidaan pitää sulina. Kahdessa mittauspisteessä virtaama mitataan avouomasta tai tierummusta akustisella, ultraäänitekniikkaan perustuvalla virtaamamittarilla (Starflow Ultrasonic Doppler Instrument Model 6526; mittaustaajuus 15 min) ja kolmessa mittauspisteessä se lasketaan avouomista V-mittapadosta ja paineantureilla (STS DL/N Series 70; mittaustaajuus $1 \mathrm{~h})$ saatavien vedenpinnan korkeustietojen avulla. Paineanturit on asennettu n. 1,5 m:n päähän Vaukkoisesta, paksusta filmivanerista olevasta mittapadosta (Thompson). Paineanturi kalibroitiin mittapatoon padon $\mathrm{V}$-aukosta manuaalisesti mitattujen vedenkorkeustietojen avulla, joita tehtiin aina mittauspisteellä käydessä. Virtaama laskettiin kaavalla (esim. Kupiainen 2010): $\mathrm{Q}=0,01416 \mathrm{x} \mathrm{h}^{5 / 2}$, missä Q on virtaama $\left(\mathrm{s}^{-1}\right) \mathrm{ja} \mathrm{h}$ on veden korkeus patoaukon pohjasta $(\mathrm{cm})$. Akustisten virtaamamittareiden ja paineantureiden kalibroimiseksi ja toiminnan varmistamiseksi virtaamaa mitattiin manuaalisesti SonTekin $^{\circledR}$ Flow Tracker ${ }^{\circledR}$-virtaamamittarilla erilaisista virtaamatilanteista useita kertoja vuodessa.
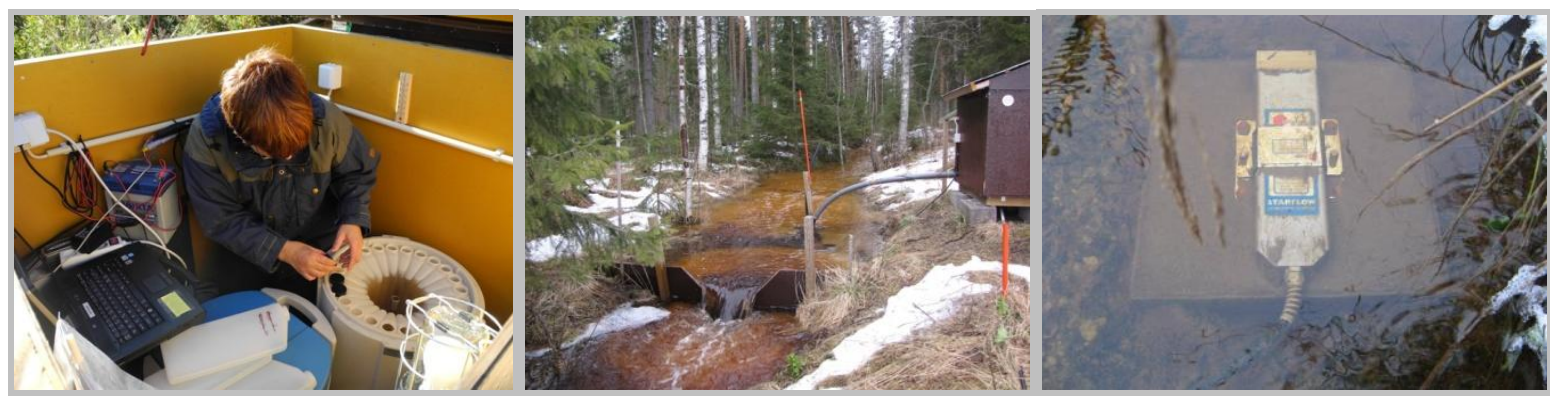

Kuva 2. a) Lämmitettävä näytteenottokoppi, johon on sijoitettu näytteenotin ja dataloggerit, b) V-mittapato ja c) akustinen virtaamamittari. Kuvat: a) MTT/Kirsi Järvenranta, b) ja c) MTT/Mari Räty. 
Vesinäytteet otettiin kokoomanäytteinä siten, että virtaaman ollessa suurta keväällä lumen sulamisen ja syksyllä syyssateiden aikaan 1,0 l:n kokoomanäyte koostettiin $50 \mathrm{ml}: n$ osanäytteistä kahden vuorokauden aikana, muuna aikana näytteenottotiheys oli harvempi (1,0 1/ 5 vrk). Kesällä veden pinnan laskiessa näytteenottimen toiminnan kannalta liian alas, näytteenottimet suljettiin ja näytteet otettiin tarvittaessa käsin yksittäisinä näytteinä. Suodattamattomista vesinäytteistä määritettiin kokonaisfosfori (SFS 3026, sov.) ja kokonaistyppi (SFS 3031, sov.) sekä suodatetuista näytteistä (huokoskoko 0,2 $\mu \mathrm{m}$ :n kalvosuodatin) liukoinen fosfori (SFS 3025, sov.), nitraattityppi (SFS 3032, sov.), ammoniumtyppi (SFS 3030), ja pitoisuudet mitattiin Skalar-autoanalysaattorilla. Lisäksi näytteistä määritettiin liukoinen orgaaninen hiili DOC (suodatus Whatman GFC, mittaus Shimadzu TOC-V), liukoinen kalsium (mittaus ICP-OES), kiintoaines (SFS-EN 872), pH ja sähkönjohtokyky (laboratoriot: MTT Jokioinen, METLA Rovaniemi). Tutkimuksessa on otettu näytteitä ja tehty virtaamamittauksia lähes kolmen havaintovuoden ajan (2011-2013).

Tutkimusvaluma-alueella olevan sääaseman toimintahäiriöiden ja -katkojen takia sademäärää ja lämpötilaa seurattiin tarkastelujaksolla Ilmatieteen laitoksen Maaninka Halola ja Vieremä Kaarakkala havaintoasemilta saatavien tietojen keskiarvona (Ilmatieteen laitos, Ilmastokeskus, MTT:n säärekisteri; Taulukko 1). Vuosi 2011 oli maan keskiosassa lämmin, ja vuoden keskilämpötila oli Maaningan havaintoasemalta mitattua vertailukauden 1981-2010 keskiarvoa korkeampi, sademäärän ollessa lähellä keskiarvoa. Vuonna 2012 keskilämpötila oli maan keskiosassa vertailukauteen verrattuna hieman keskiarvoa alhaisempi, mutta vuosi oli tavanomaista sateisempi, vaikka sademäärissä oli suuriakin paikallisia vaihteluita.

Lumen sulamisvesien aiheuttaman valunnan suuruuden arvioimiseksi lumessa olevan veden määrä eli lumen vesiarvo mitattiin maaliskuun loppupuolella kattaen tutkimusvaluma-alueen eri maastotyypit (Taulukko 1). Tarkastelujaksolla 2011-2012 lumen vesiarvo määritettiin lumipuntarilla ja lumen syvyys mitattiin $\mathrm{n}$. 16 eri mittauspisteestä, mittauksia tehtiin $2-3 \mathrm{kpl} /$ mittauspiste.

Kirmanjärveen laskevassa Ruostepurossa olevan mittauspisteen mitattuja virtaamatietoja verrattiin Suomen ympäristökeskuksen (SYKE) käytössä olevasta Vesistömallijärjestelmästä poimittuihin, Ruostepuron osavaluma-alueelle VEMALA-mallilla laadittuihin virtaamatietoihin (SYKE-WSFSVEMALA; 04516 Ruostepuro, simuloidut tiedot).

\section{Tulokset ja tarkastelu}

Kuvassa 3 on esitetty tarkastelujaksolla 2011-2012 mittauspisteille laaditut virtaamien alustavat summakäyrät sekä vertailuksi VEMALA-mallin tiedoista Ruostepuron havaintopisteelle (04 516) laadittu summakäyrä (SYKE-WSFS-VEMALA). Virtaama oli suurimmillaan noin kolme viikkoa kestävän lumen nopean sulamisen aiheuttaman tulvahuipun aikana, ja se muodosti noin puolet koko vuoden virtaamasta vuonna 2011 ja noin kolmasosan sateisena vuonna 2012. Tämän takia keväällä sulamisen aiheuttaman ylivirtaaman aikana tulevan ravinnekuorman merkitys kokonaiskuormituksen kannalta on keskeinen. Suomessa valunta on tyypillisesti suurimmillaan syyssateiden ja keväällä lumen sulamisen aikaan, ja siten valtaosa maatalouden aiheuttamasta fosforikuormituksesta ajoittuukin näihin kasvukauden ulkopuolella esiintyviin suuriin ja lyhytaikaisiin valumahuippuihin (Rekolainen 1992, Puustinen ym. 2007). Tavanomaista sateisempana vuonna 2012 koko tutkimusvaluma-aluetta edustavan Ruostepuron mittauspisteen 1 virtaaman summakäyrän muoto oli kevään jälkeen kesä- ja syyssateiden takia lähes tasaisesti nouseva ja vuoden vesimäärä oli kaksinkertainen vuoteen 2011 verrattuna.

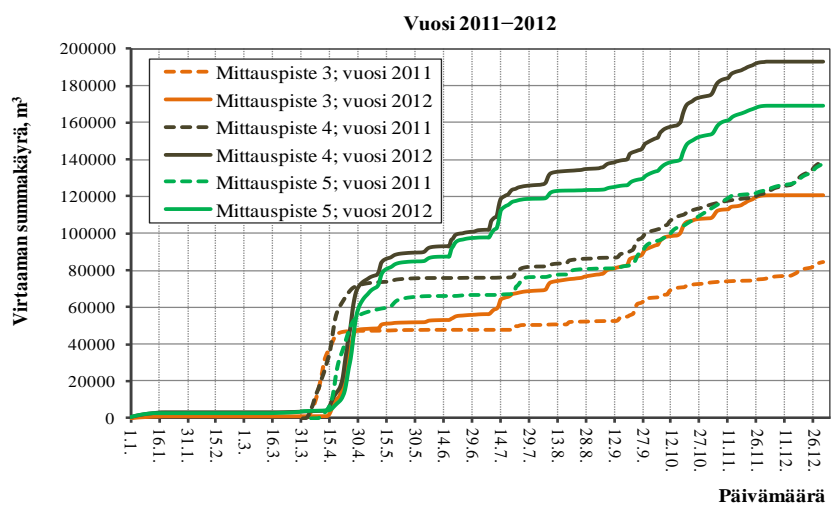




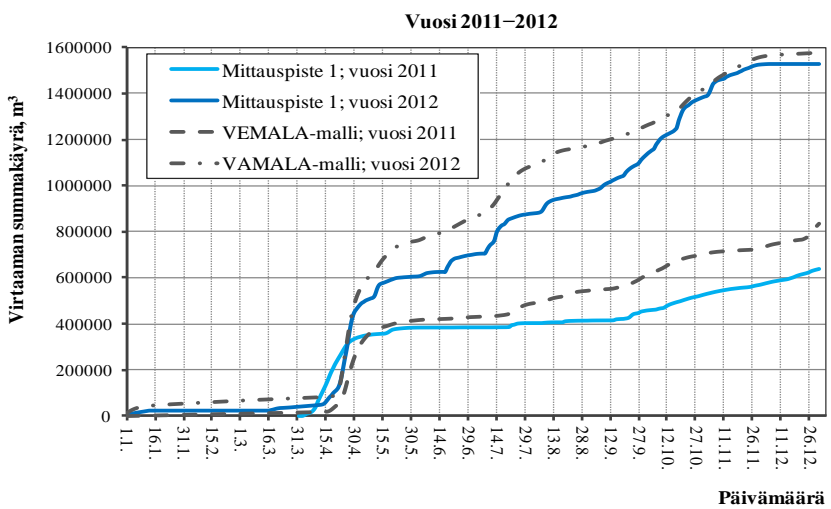

Kuva 3. a) Tutkimusvaluma-alueella oleville virtaamamittauspisteille 3, 4 ja 5 (ks. kuva 1) laaditut virtaamien alustavat summakäyrät tarkastelujaksolla 2011-2012. b) Kirmanjärveen laskevasta Ruostepurosta mitattujen virtaamatietojen perusteella laaditut summakäyrät; vuonna 2011 keskivalunta oli n. $71 \mathrm{~s}^{-1} \mathrm{~km}^{-2}$ ja vuonna 2012 se oli n. $17 \mathrm{l} \mathrm{s}^{-1} \mathrm{~km}^{-1}$. Mitatuista virtaamatiedoista laadittua summakäyrää verrattiin VEMALA-mallin tietojen perusteella Ruostepuron havaintopisteelle laadittuun summakäyrään (SYKE-WSFS-VEMALA; 04516 Ruostepuro, simuloidut tiedot). Huomaa, että kuvissa y-akselin asteikko on erilainen.

Akustinen virtaamamittari on osoittautunut käyttökelpoiseksi etenkin lumen sulamisen aiheuttamien hankalien ylivirtaamien tilanteissa. Mittapadot kaivettiin lumesta esille maaliskuun loppupuolella ja tarvittaessa V-aukoista poistettiin muodostunut jää vielä ennen sulamisvalunnan alkamista. Sulamisen alkuvaiheessa ojat tulvivat voimakkaasti ja peltovaltaisilla mittauspisteillä 3 ja 4 sulamisvesi tulvi mittapatojen yli, eikä virtaama ollut luotettavasti mitattavissa, mikä voi pienentää ko. mittauspisteille laadittuja virtaaman summakäyriä. Metsäisellä seuranta-alueella vastaavaa ei tapahtunut.

Tarkastelujaksolla 2011-2012 vesinäytteissä oli liukoista fosforia $0-1,23 \mathrm{mg} \mathrm{P} \mathrm{l}^{-1}$ ja kokonais-fosforia $0,01-1,80 \mathrm{mg} \mathrm{P}^{-1}$ (Taulukko 2). Lumen sulamisen alkuvaiheessa pitoisuudet olivat korkeita fosforin ollessa todennäköisesti peräisin kasvinjäänteistä, mutta pitoisuudet laimenivat nopeasti vir-taaman kasvaessa. Kun virtaaman oli pientä kesän ja syksyn aikana, pitoisuudet kohosivat fosforin konsentroituessa ojavesiin. Liukoisena oleva fosfori muodosti keskimäärin $47 \%$ vesinäytteiden koko-naisfosforista, mutta sen osuus vaihteli paljon (0-100\%) näytteenottopisteen ja -ajan suhteen. Syksyl-lä 2012 esiintyi ajoittain kohonneita kiintoaineen ja kokonaisfosforin pitoisuuksia, mikä johtui osittain runsaista sateista sekä tutkimusvaluma-alueella sijaitsevan kosteikon kunnostamistöistä.

Tarkastelujaksolla 2011-2012 pienelle peltovaltaiselle (pelto-\% 100) seurantakohteelle valumaalueen pinta-alayksikköä kohti laskettu alustava kokonaisfosforihuuhtouma n. $0,9 \mathrm{~kg} \mathrm{P} \mathrm{ha}^{-1} \mathrm{a}^{-1}$ vastasi Vuorenmaan ym. (2002) esittämää arviota $1,1 \mathrm{~kg} \mathrm{ha}^{-1} \mathrm{a}^{-1}$ (josta on vähennetty luonnon taustahuuhtouma), ja kokonaistypen (n. $26 \mathrm{~kg} \mathrm{ha}^{-1} \mathrm{a}^{-1}$ ) osalta se oli Vuorenmaan ym. (2002) arviota korkeampi $\left(15 \mathrm{~kg} \mathrm{ha}^{-1} \mathrm{a}^{-1}\right.$ ) (Taulukko 3). Metsän osuuden kasvaessa (pelto-\% n. 50) ominaiskuormitusarvio oli kokonaisfosforille $\mathrm{n} .0,5 \mathrm{~kg} \mathrm{ha}^{-1} \mathrm{a}^{-1}$ ja kokonaistypelle $\mathrm{n} .15 \mathrm{~kg} \mathrm{ha}^{-1} \mathrm{a}^{-1}$. Luonnontilaisille kivennäismaille ja soille kirjallisuudessa esitetyt huuhtouma-arviot ovat huomattavasti peltomaille esitettyjä pienempiä, kokonaisfosforille keskimäärin $0,049 \mathrm{~kg} \mathrm{ha}^{-1} \mathrm{a}^{-1}\left(0,02-0,15 \mathrm{~kg} \mathrm{ha}^{-1} \mathrm{a}^{-1}\right)$ ja kokonaistypelle keskimäärin $1,3 \mathrm{~kg} \mathrm{ha}^{-1} \mathrm{a}^{-1}\left(0,3-2,3 \mathrm{~kg} \mathrm{ha}^{-1} \mathrm{a}^{-1}\right.$ ) (Finér ym. 2010). Metsäalueelta tulevan ojaveden ajoittain korkeat fosforipitoisuudet olivat todennäköisesti seurausta pistemäisestä kuormituslähteestä, joka nosti fosforihuuhtoumaa luonnontilaisiin metsäalueisiin verrattuna. Tämän vaikutus on kuitenkin poistumassa, koska alue on liitetty kunnallisen keskitetyn viemäröinnin piiriin. Peltoviljelyalueelta tulevan kokonaistypen kuormitus oli moninkertainen metsäalueeseen $\left(2,3 \mathrm{~kg} \mathrm{ha}^{-1} \mathrm{a}^{-1}\right)$ verrattuna. Koko tutkimusvaluma-alueelta tulevan kokonaisfosforin ja -typen huuhtouma oli $\mathrm{n} .0,6 \mathrm{~kg} \mathrm{P} \mathrm{ha}^{-1} \mathrm{a}^{-1} \mathrm{ja} 12 \mathrm{~kg}$ $\mathrm{Nha} \mathrm{a}^{-1}$. 
Taulukko 1. Kuukauden keskimääräinen sademäärä $(\mathrm{mm})$ ja lämpötila $\left({ }^{\circ} \mathrm{C}\right)$ sekä tutkimusvaluma-alueelta mitattu lumen keskimääräinen vesiarvo $\left(\mathrm{kg} \mathrm{m}^{-2}\right)$ ja syvyys $(\mathrm{cm})$.

\begin{tabular}{|c|c|c|c|c|c|c|c|c|c|c|c|c|c|}
\hline & & & & & & Kuuk & & & & & & & \\
\hline & 1 & 2 & 3 & 4 & 5 & 6 & 7 & 8 & 9 & 10 & 11 & 12 & \\
\hline $\begin{array}{r}\text { *Sademäärä, mm } \\
\text { Vuosi } 2011\end{array}$ & 72 & 10 & 20 & 10 & 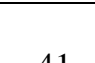 & 40 & 142 & 87 & 07 & 54 & 16 & 87 & $\Sigma, \mathrm{mm}$ \\
\hline $\begin{array}{l}\text { Vuos1 } 2011 \\
\text { Vuosi } 2012\end{array}$ & 37 & $\begin{array}{l}19 \\
49\end{array}$ & $\begin{array}{l}22 \\
22\end{array}$ & $\begin{array}{l}18 \\
46\end{array}$ & $\begin{array}{l}41 \\
50\end{array}$ & $\begin{array}{r}49 \\
120\end{array}$ & $\begin{array}{l}143 \\
140\end{array}$ & $\begin{array}{l}81 \\
79\end{array}$ & $\begin{array}{l}87 \\
82\end{array}$ & $\begin{array}{l}54 \\
76\end{array}$ & $\begin{array}{l}16 \\
52\end{array}$ & $\begin{array}{l}82 \\
49\end{array}$ & $\begin{array}{l}690 \\
802\end{array}$ \\
\hline **Pitkäaikainen 1981-2010 & 44 & 33 & 35 & 30 & 47 & 66 & 77 & 74 & 53 & 55 & 50 & 47 & 611 \\
\hline *Lämpötila, ${ }^{\circ} \mathrm{C}$ & & & & & & & & & & & & & Keskiarvo, ${ }^{\circ} \mathrm{C}$ \\
\hline Vuosi 2011 & $-9,2$ & $-15,7$ & $-3,7$ & 4,2 & 9,1 & 15,8 & 18,8 & 14,6 & 10,7 & 4,8 & 1,1 & $-0,5$ & 4,2 \\
\hline Vuosi 2012 & $-9,7$ & $-12,3$ & $-2,5$ & 0,8 & 9,1 & 12,7 & 16,5 & 13,6 & 9,2 & 3,4 & $-0,1$ & $-12,5$ & 2,3 \\
\hline **Pitkäaikainen 1981-2010 & $-9,3$ & $-9,4$ & $-4,1$ & 1,9 & 8,9 & 14,1 & 17,0 & 14,5 & 9,4 & 3,9 & $-2,2$ & $-6,8$ & 3,2 \\
\hline Lumen vesiarvo, $\mathrm{kg} \mathrm{m}^{-2} ; \mathrm{mm}$ & & & Keskiarvo & Min & Maks & & & & & & & & \\
\hline Vuosi 2011 & & & 146 & 112 & 186 & & & & & & & & \\
\hline Vuosi 2012 & & & 110 & 60 & 180 & & & & & & & & \\
\hline Lumen syvyys, cm & & & Keskiarvo & Min & Maks & & & & & & & & \\
\hline Vuosi 2011 & & & 66 & 56 & 76 & & & & & & & & \\
\hline Vuosi 2012 & & & 49 & 31 & 71 & & & & & & & & \\
\hline
\end{tabular}

* Keskiarvot on laskettu Ilmatieteen laitoksen havaintoasemien Maaninka Halola ja Vieremä Kaarakkala säätiedoista (Ilmatieteen laitos, Ilmastokeskus; MTT:n säärekisteri).

** Ilmatieteen laitoksen havaintoasema Maaninka, Halola (MTT:n säärekisteri).

Taulukko 2. Liukoisen fosforin, kokonaisfosforin ja -typen, liukoisen orgaanisen hiilen (DOC) ja kiintoaineksen pitoisuuksien keski-, minimi- ja maksimiarvot (mg $1^{-1}$ ) sekä pH ja sähkönjohtokyky Ruostepuron tutkimusosavaluma-alueiden ojien vesinäytteissä (näytteenottopisteet 1-5; ks. kuva 1) tutkimusjaksolla $2011-2012$.

\begin{tabular}{|c|c|c|c|c|c|c|c|c|c|c|c|c|c|c|c|c|c|c|c|c|c|c|}
\hline \multirow[b]{2}{*}{$\begin{array}{l}\text { Mittaus- } \\
\text { piste }\end{array}$} & \multirow[b]{2}{*}{$\mathrm{n}$} & \multicolumn{3}{|c|}{$\begin{array}{l}\text { Liukoinen-P } \\
\mathrm{mg} \mathrm{l}^{-1}\end{array}$} & \multicolumn{3}{|c|}{$\begin{array}{c}\text { Kokonais-P, } \\
\mathrm{mg} \mathrm{l}^{-1}\end{array}$} & \multicolumn{3}{|c|}{$\begin{array}{c}\text { Kokonais-N } \\
\mathrm{mg} \mathrm{l}^{-1}\end{array}$} & \multicolumn{3}{|c|}{$\begin{array}{l}\mathrm{DOC} \\
\mathrm{mg} \mathrm{l}^{-1}\end{array}$} & \multicolumn{3}{|c|}{$\begin{array}{c}\text { Kiintoaines } \\
\mathrm{mg} \mathrm{l}^{-1}\end{array}$} & \multicolumn{3}{|c|}{$\mathrm{pH}$} & \multicolumn{3}{|c|}{$\begin{array}{c}\text { Sähkönjohtokyky } \\
\mathrm{mS} \mathrm{cm}^{-1}\end{array}$} \\
\hline & & $\begin{array}{l}\text { Keski- } \\
\text { arvo }\end{array}$ & Min & Maks & $\begin{array}{c}\text { Keski- } \\
\text { arvo }\end{array}$ & Min & Maks & $\begin{array}{l}\text { Keski- } \\
\text { arvo }\end{array}$ & Min & Maks & $\begin{array}{l}\text { Keski- } \\
\text { arvo }\end{array}$ & Min & Maks & $\begin{array}{l}\text { Keski- } \\
\text { arvo }\end{array}$ & Min & Maks & $\begin{array}{l}\text { Keski- } \\
\text { arvo }\end{array}$ & Min & Maks & $\begin{array}{c}\text { Keski- } \\
\text { arvo }\end{array}$ & Min & Maks \\
\hline 2011 & & & & & & & & & & & & & & & & & & & & & & \\
\hline 1 & 26 & 0,06 & 0,02 & 0,15 & 0,17 & 0,07 & 0,51 & 4,4 & 0,9 & 15 & 25 & 17 & 41 & 16 & 0,0 & 107 & 7,1 & 6,6 & 7,4 & 138 & 56 & 322 \\
\hline 2 & 26 & 0,06 & 0,03 & 0,17 & 0,26 & 0,12 & 0,69 & 6,4 & 1,5 & 22 & 23 & 15 & 35 & 26 & 0,0 & 113 & 7,1 & 6,5 & 8,2 & 193 & 137 & 313 \\
\hline 3 & 26 & 0,08 & 0,02 & 0,18 & 0,24 & 0,06 & 1,63 & 6,7 & 3,1 & 20 & 12 & 5,4 & 22 & 120 & 0,0 & 2015 & 7,2 & 6,5 & 8,4 & 210 & 153 & 269 \\
\hline 4 & 17 & 0,06 & 0,00 & 0,12 & 0,14 & 0,04 & 0,33 & 7,5 & 1,3 & 35 & 19 & 13 & 33 & 27 & 0,0 & 80 & 6,9 & 6,4 & 7,3 & 160 & 55 & 421 \\
\hline 5 & 24 & 0,31 & 0,00 & 1,23 & 0,48 & 0,01 & 1,79 & 1,5 & 0,7 & 3,1 & 42 & 26 & 54 & 2,9 & 0,0 & 17 & 5,9 & 5,2 & 6,8 & 65 & 38 & 137 \\
\hline 2012 & & & & & & & & & & & & & & & & & & & & & & \\
\hline 1 & 30 & 0,07 & 0,03 & 0,21 & 0,40 & 0,05 & 0,56 & 3,2 & 1,3 & 9,5 & 23 & 13 & 38 & 41 & 0,0 & 279 & 6,9 & 6,6 & 7,3 & 112 & 54 & 223 \\
\hline 2 & 27 & 0,08 & 0,02 & 0,21 & 0,25 & 0,08 & 1,40 & 4,0 & 1,1 & 11 & 19 & 12 & 35 & 48 & 0,0 & 943 & 7,0 & 6,5 & 7,8 & 147 & 83 & 262 \\
\hline 3 & 26 & 0,09 & 0,03 & 0,24 & 0,22 & 0,06 & 0,98 & 6,3 & 1,7 & 13 & 10 & 6,2 & 20 & 20 & 0,0 & 140 & 7,0 & 6,2 & 7,7 & 205 & 128 & 242 \\
\hline 4 & 25 & 0,06 & 0,01 & 0,22 & 0,14 & 0,03 & 0,49 & 2,4 & 1,1 & 7,3 & 18 & 11 & 30 & 44 & 0,0 & 205 & 6,8 & 6,5 & 7,6 & 90 & 43 & 157 \\
\hline 5 & 24 & 0,23 & 0,06 & 1,00 & 0,42 & 0,07 & 1,80 & 1,9 & 0,8 & 8,7 & 37 & 27 & 54 & 3,7 & 0,0 & 12 & 5,8 & 5,1 & 7,1 & 58 & 30 & 181 \\
\hline
\end{tabular}


Taulukko 3. Ruostepuron tutkimusvaluma-alueen ja sen osa-alueiden (ks. kuva 1) vedenlaatumuuttujien alustavat ominaiskuormitusarviot $\left(\mathrm{kg} \mathrm{ha}^{-1} \mathrm{a}^{-1}\right)$ tarkastelujaksolla 2011-2012.

\begin{tabular}{|c|c|c|c|c|c|c|c|c|c|c|c|}
\hline \multirow{2}{*}{$\begin{array}{l}\text { Mittaus- } \\
\text { piste }\end{array}$} & & \multicolumn{10}{|c|}{$\mathrm{kg} \mathrm{ha}^{-1} \mathrm{a}^{-1}$} \\
\hline & Pelto- $\%$ & \multicolumn{2}{|c|}{ Liukoinen-P } & \multicolumn{2}{|c|}{ Kokonais-P } & \multicolumn{2}{|c|}{ Kokonais-N } & \multicolumn{2}{|c|}{ DOC } & \multicolumn{2}{|c|}{ Kiintoaine } \\
\hline & & 2011 & 2012 & 2011 & 2012 & 2011 & 2012 & 2011 & 2012 & 2011 & 2012 \\
\hline 1 & 32 & 0,1 & 0,4 & 0,3 & 0,9 & 9 & 15 & 53 & 115 & 27 & 115 \\
\hline 3 & 100 & 0,2 & 0,4 & 1,0 & 0,9 & 23 & 28 & 37 & 43 & 706 & 121 \\
\hline 4 & 50 & 0,1 & 0,2 & 0,3 & 0,6 & 21 & 9 & 52 & 67 & 74 & 210 \\
\hline 5 & $<1$ & $0,3^{*}$ & $0,3^{*}$ & $0,4^{*}$ & $0,4^{*}$ & 2 & 3 & 63 & 63 & 5 & 7 \\
\hline
\end{tabular}

* Sisältää myös pistemäisen kuormituslähteen.

\section{Johtopäätökset}

Alustavat tulokset eivät osoita nurmiviljelyyn pohjautuvasta nautakarjataloudesta tulevan fosforikuormituksen olevan poikkeuksellisen suurta. Toisaalta on huomioitava leville suoraan käyttökelpoisena olevan liukoisen fosforin varsin suuri osuus kokonaisfosforin huuhtoumasta. Tulokset ovat kuitenkin vasta kahden vuoden ajalta ja nurmenviljelyn aiheuttaman ravinnekuormituksen luotettava arviointi edellyttää riittävää näytteenottotiheyttä ja hydrologisen vuosivaihtelun takia pitkäaikaista seurantatutkimusta. Lisäksi leutojen ja sateisten talvien yleistyminen tulee muuttamaan valunnan ajallista jakautumista, mikä lisää syys- ja talvikuukausien aikaista valuntaa ja siten myös fosforin huuhtoutumisriskiä talvikaudella.

\section{Kirjallisuus}

Finér, L., Mattsson, T., Joensuu, S., Koivusalo, H., Laurén, A., Makkonen, T., Nieminen, M., Tattari, S., Ahti, E., Kortelainen, P., Koskiaho, J., Leinonen, A., Nevalainen, R., Piirainen, S., Saarelainen, J. Sarkkola, S. \& Vuollekoski, M. 2010. Metsäisten valuma-alueiden vesistökuormituksen laskenta. Suomen ympäristö 10. Suomen ympäristökeskus. Helsinki. $33 \mathrm{~s}$.

Kauppinen, E. 2006. Kirmanjärven fosforitaseet ja kunnostuksen pääpiirteet vuodelle 2006. Vesi-Eko Oy Water-Eco Ltd. $79 \mathrm{~s}$.

Kupiainen, V. 2010. Pohjaveden purkautuminen metsäojiin Rokuan harjualueella ja ojan kunnostus padottamalla. Diplomityö. Oulun yliopisto, Prosessi- ja ympäristötekniikan osasto, Vesi- ja ympäristötekniikan laboratorio. $68 \mathrm{~s}+10$ liitesivua.

Muukkonen, P., Hartikainen, H., Lahti, K., Särkelä, A., Puustinen, M. \& Alakukku, L. 2007. Influence of no-tillage on the distribution and lability of phosphorus in Finnish clay soils. Agriculture, Ecosystems and environment 120: 299-306.

Pohjois-Savon ELY-keskus. 2010. Pohjois-Savon vesienhoidon toimenpideohjelma vuosille 2010-2015. Pohjois-Savon elinkeino-, liikenne- ja ympäristökeskuksen julkaisuja 01/2010. $225 \mathrm{~s}$.

Puustinen, M., Tattari, S., Koskiaho, J. \& Linjama, J. 2007. Influence of seasonal and annual hydrological variations on erosion and phosphorus transport from arable areas in Finland. Soil \& Tillage Research 93: 44-55.

Rekolainen, S. 1992. Maatalouden aiheuttama fosfori- ja typpikuorma vesistöihin. Julkaisussa: Rekolainen, S. \& Kauppi, L. (toim.). Maatalous- ja vesien kuormitus. Yhteistutkimusprojektin tutkimusraportit. Vesi- ja ympäristöhallituksen monistesarja 359. Vesi- ja ympäristöhallitus, Helsinki. s. 9-15. 206 s.

Saarela, I. \& Vuorinen, M. 2010. Stratification of soil phosphorus, pH, and macro-cations under intensively cropped grass ley. Nutrient Cycling in Agroecosystems 86: 367-381.

Saarijärvi, K., Karppinen, M., Uusi-Kämppä, J., Turtola, E. \& Virkajärvi, P. 2006. Laitumen fosforitalous ja vesistökuormituksen hallinta. s. 23-33. Teoksessa: Alakkku, L. (toim.). Maaperän prosessit - pellon kunnon ja ympäristönhoidon perusta. Maa- ja elintarviketalous $82.128 \mathrm{~s}$.

Sharpley, A.N. 1995. Dependence of runoff phosphorus on extractable soil phosphorus. Journal of Environmental Quality 24: 920-926.

Turtola, E. \& Kemppainen, E. 1998. Nitrogen and phosphorus losses in surface runoff and drainage water after application of slurry and mineral fertilizer to perennial grass ley. Agricultural and Food Science in Finland 7: 569 -581 .

Turtola, E. \& Yli-Halla, M. 1999. Fate of phosphorus applied in slurry and mineral fertilizer: accumulation in soil and release into surface runoff water. Nutrient Cycling in Agroecosystems 55: 165-174.

SYKE-WSFS-VEMALA. Vesistömallijärjestelmän vedenlaatuosio. Tiedot lainattu 19.12.2013.

Vuorenmaa, J., Rekolainen, S., Lepistö, A., Kenttämies, K. \& Kauppila, P. 2002. Losses of nitrogen and phosphorus from agricultural and forest areas in Finland during the 1980s and 1990s. Environmental Monitoring and Assessment 76: 213-248. 